\title{
The Technology Readiness Analysis of Electronic Information System
}

\author{
Hua Wang, Hongzhi Xiao, Fajiang Zhang, Xiaoluan Liang \\ Beijing Shi QingHe DaLou Zi Jiu, Beijing, 100085, China \\ email: 919wh_cn@sina.com
}

Keywords: Technology Readiness; Technology Readiness Levels; Electronic Information System

\begin{abstract}
Based on the synopsis of electronic information system and technology readiness theory, this paper puts forward the technology readiness model and the technology readiness levels of electronic information system, sets forth a series of technology readiness criteria, gives an application of technology readiness assessment to one information processing system, and introduces the relevant measures such as strengthening overall scheme, reinforcing assessment basis and consolidating process management. This will benefit the further technology improvement of electronic information system.
\end{abstract}

\section{Introduction}

Along with the rising of independent innovation mode, the application of a great deal advanced and novel technology has accelerated the rapid progress of electronic information system, and brought system development a lot of unexpectedness.

Technology Readiness (TR) is the maturity state and extent of one technology after investigation, exploitation, validation and application. Technology Readiness Level (TRL) is the partition and metric of the technology maturity state during the process of rationale foundation, technology investigation, test validation and engineering application, which indicates the technology mastery degree and application level. Technology Readiness Assessment (TRA) is an approach that quantitively measures and evaluates the fulfillment extent of technology with respect to engineering project goal, and it is helpful to carry out the identification and control of technology risk [1][2].

Technology Readiness theory has widely been applied to equipment development and related technology assessment since the birth on seventies of twenty century. It is the important tool that could accelerate technology maturity, ensure development quality and support milestone decision.

(1) It can enhance the management of system technology state.

(2) It can strengthen technology programming management and help to establish evolution road map of engineering technology.

(3) It can improve the schedule management via the actualization and supervision of technology evolution by the comparison between present and target technology state.

Technology Readiness theory aims at the technology conception, technology state and technology capabilities according to standardized metrics and grades so as to ascertain and improve the maturity extent of relevant technologies during the system construction.

\section{Technology Readiness Model}

The engineering process of electronic information system generally includes user demands, scheme design, primary system and testing, formal system and testing, system finalization and system operation phases. The Technology Readiness Model of electronic information system is shown in Figure 1. In addition, the analysis steps of system TR are usually as follows.

(1) Establishment of TRL demands. TRL demands are generally derived from operational needs of electronic information system, and thus TRL plan is formulated so as to establish personnel arrangement, work assignment, schedule node and outcome modality.

(2) Identification of critical technology elements. Critical technology elements are identified via work breakdown structure. The key extent of system technology mainly lies in the significance and 
difficulty level, and the related TRL objective should be made certain with respect to each development phases.

(3) Listing of TRA criteria. TRA criteria are practically thought over and set out in detail. And project team need make sure the assignment and requirements of critical technology investigation, and achieve technology evolvement in the light of technology maturity rules, so as to arrive at the target level from present level.

(4) TRA implementation. TRAs are implemented before milestones such as scheme, formal system and finalization phase reviews, so that the development state of each critical technology can be exactly grasped and properly managed.

(5) TRA report. TRA report is compiled and referred to organization department that concerns task situation, assessment result and related suggestions so as to assist the decision of project phase transfer.

(6) TRL improvement. In respect to those technology items that have not achieved the demands of TRL, project team should set down the pertinent plan, and put it in practice after examination and approval to step up the related technology readiness of electronic information system.

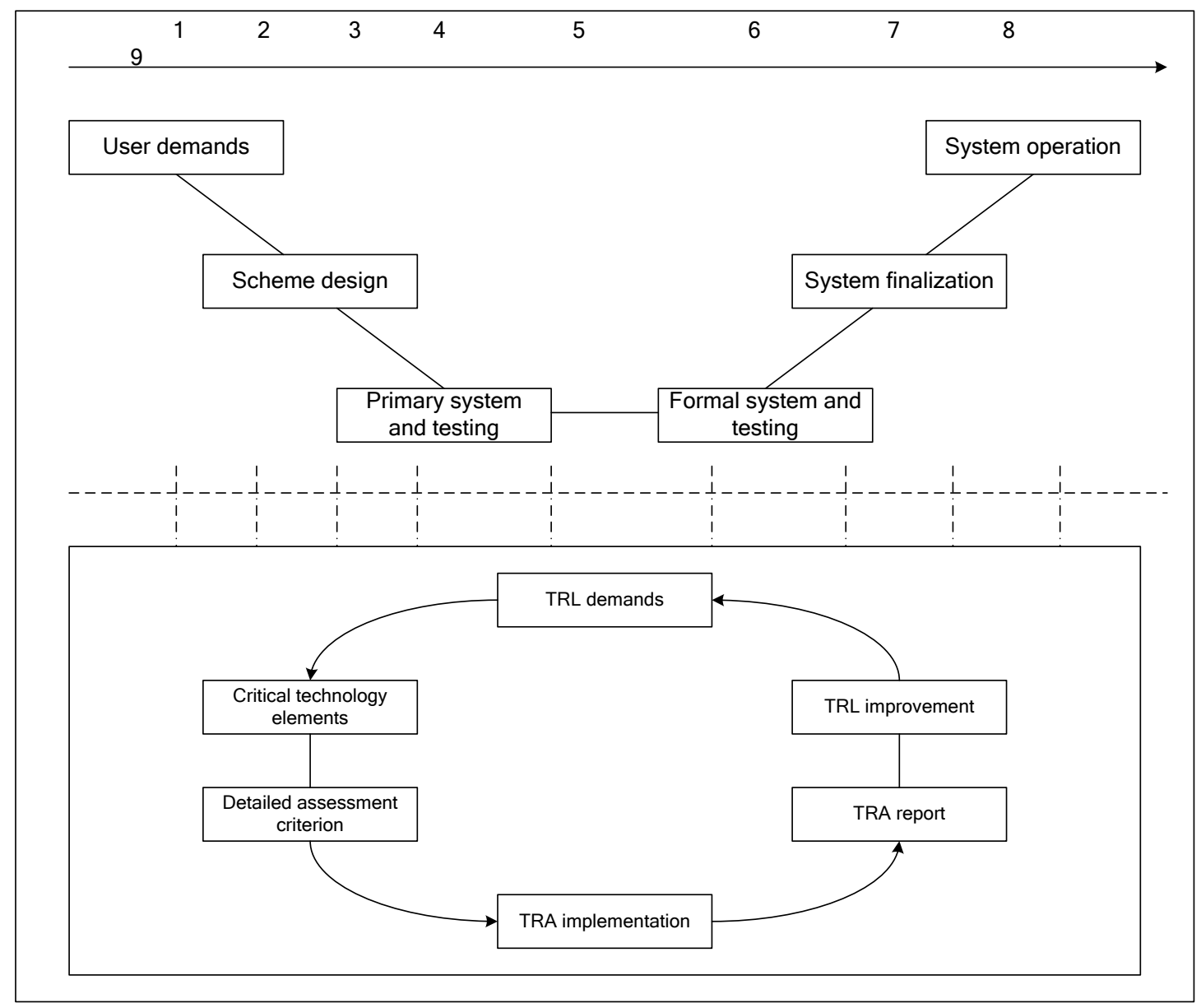

Fig.1. The Technology Readiness Model of electronic information system

The TRL definition of electronic information system is described in Table 1. 
Table 1. The TRL definition of electronic information system

\begin{tabular}{|c|c|c|}
\hline TRL & Definition & Outcome \\
\hline 1 & $\begin{array}{l}\text { To put forward keystone and draw up formal } \\
\text { report }\end{array}$ & Paper or research report \\
\hline 2 & $\begin{array}{l}\text { To put forward technology conception and } \\
\text { application imagination }\end{array}$ & $\begin{array}{c}\text { Research and experimentation } \\
\text { report }\end{array}$ \\
\hline 3 & $\begin{array}{l}\text { To accomplish the feasibility validation of the } \\
\text { above conception and imagination }\end{array}$ & $\begin{array}{c}\text { Feasibility report and elements } \\
\text { model }\end{array}$ \\
\hline 4 & $\begin{array}{l}\text { To accomplish the validation of elements sample } \\
\text { and assembly under laboratory circumstances }\end{array}$ & Elements sample \\
\hline 5 & $\begin{array}{l}\text { To accomplish the validation of model sample and } \\
\text { assembly under relevant circumstances }\end{array}$ & Prototype system \\
\hline 6 & $\begin{array}{l}\text { To accomplish the validation of primary system or } \\
\text { subsystem under relevant circumstances }\end{array}$ & Primary system \\
\hline 7 & $\begin{array}{l}\text { To accomplish the validation of formal system } \\
\text { under typical operational circumstances }\end{array}$ & Formal system \\
\hline 8 & $\begin{array}{l}\text { To accomplish the validation of practical system } \\
\text { under operational circumstances }\end{array}$ & Finalized system \\
\hline 9 & $\begin{array}{l}\text { To accomplish the operational mission of practical } \\
\text { system }\end{array}$ & Operational system \\
\hline
\end{tabular}

\section{TRL criteria and conditions}

It is necessary to make clear TRA criteria for every critical technology, and the conditions of TRLs can be concreted [3][4]. Some level conditions are described in Table 2.

Table 2. The Concrete Conditions of TRL 4 and TRL 8

\begin{tabular}{|c|l|l|}
\hline No. & \multicolumn{1}{|c|}{ Condition content of TRL 4 } & \multicolumn{1}{|c|}{ Condition content of TRL 8 } \\
\hline 1 & $\begin{array}{l}\text { System has clear application context, and } \\
\text { system goal and overall demands are } \\
\text { specified. }\end{array}$ & $\begin{array}{l}\text { System application demands are clear, and } \\
\text { system indexes are specified. }\end{array}$ \\
\hline 2 & $\begin{array}{l}\text { System technology scheme and approach are } \\
\text { put forward. }\end{array}$ & $\begin{array}{l}\text { System is put through the base tests which } \\
\text { validate all the function and performance. }\end{array}$ \\
\hline 3 & $\begin{array}{l}\text { Sample, assembly and function modules are } \\
\text { designed, processed and assessed, and their } \\
\text { main indexes satisfy the related demands. }\end{array}$ & $\begin{array}{l}\text { System is put through the user tests which } \\
\text { assess the operational performance and } \\
\text { applicability. }\end{array}$ \\
\hline 4 & $\begin{array}{l}\text { Sample, assembly and function modules are } \\
\text { integrated into principium equipment, and the } \\
\text { function characteristics of related technology } \\
\text { application are validated. }\end{array}$ & $\begin{array}{l}\text { System is finalized, and technology indexes } \\
\text { entirely meet the practical needs. }\end{array}$ \\
\hline 5 & $\begin{array}{l}\text { Principium equipment is tested, and the } \\
\text { feasibility of technology scheme and approach } \\
\text { is validated. }\end{array}$ & $\begin{array}{l}\text { Production technics is stable and ripe for batch } \\
\text { production. }\end{array}$ \\
\hline 6 & $\begin{array}{l}\text { Key components and assemblies are tested and } \\
\text { trial-manufactured. }\end{array}$ & $\begin{array}{l}\text { Eligible suppliers are supervised, and the key } \\
\text { materials and wares are steadily supported. }\end{array}$ \\
\hline 7 & $\begin{array}{l}\text { Detailed analysis is made, and software } \\
\text { requirements of function modules are } \\
\text { established. }\end{array}$ & $\begin{array}{l}\text { Software configuration management and } \\
\text { classification tests are implemented, and } \\
\text { development library and controlled library are } \\
\text { effectively supervised. }\end{array}$ \\
\hline 8 & $\begin{array}{l}\text { The analysis of data format and requirements } \\
\text { is made. }\end{array}$ & Software finalization testing is implemented. \\
\hline 9 & $\begin{array}{l}\text { Software is tested with typical data package. } \\
\text { Software user documents are established and } \\
\text { controlled. }\end{array}$ \\
\hline
\end{tabular}




\section{Case Study}

One information processing system is developed to implement such functions as information receiving, analysis, decision and transfer, and the system life cycle mainly contains user demands, scheme design, primary system and testing, formal system and testing, system finalization, and system operation phases.

After the relevant system demonstration, work breakdown and special reviews, it is considered that the information processing system has three critical technologies, i.e. information syncretization technology, file transfers technology and data synchronization technology, and the respective criteria of TRL corresponding to the critical technologies are further concreted.

System function and performance demands are made certain in the system overall scheme, and the prototype system is developed and tested to validate the feasibility of main functions and technologies in the scheme design phase; the formal system is continually integrated and completely tested, and the function and performance indexes meet the operational needs in the formal system phase; and the system is further improved and practically tested to validate that system technology indexes entirely satisfy the operational demands with the production technics steady and software finalization testing implemented in the system finalization phase.

The TRA activities are implemented before the milestone reviews in the scheme design, the formal system, and the system finalization phases. And the assessment results are shown in Figure 2. In the light of the lowest level principal, we can deduce that the TRLs of the information processing system are respectively 4, 7 and 8 with regard to the related phases. Moreover, the analysis and assessment of technology readiness status is summarized, audited and reported [5][6].

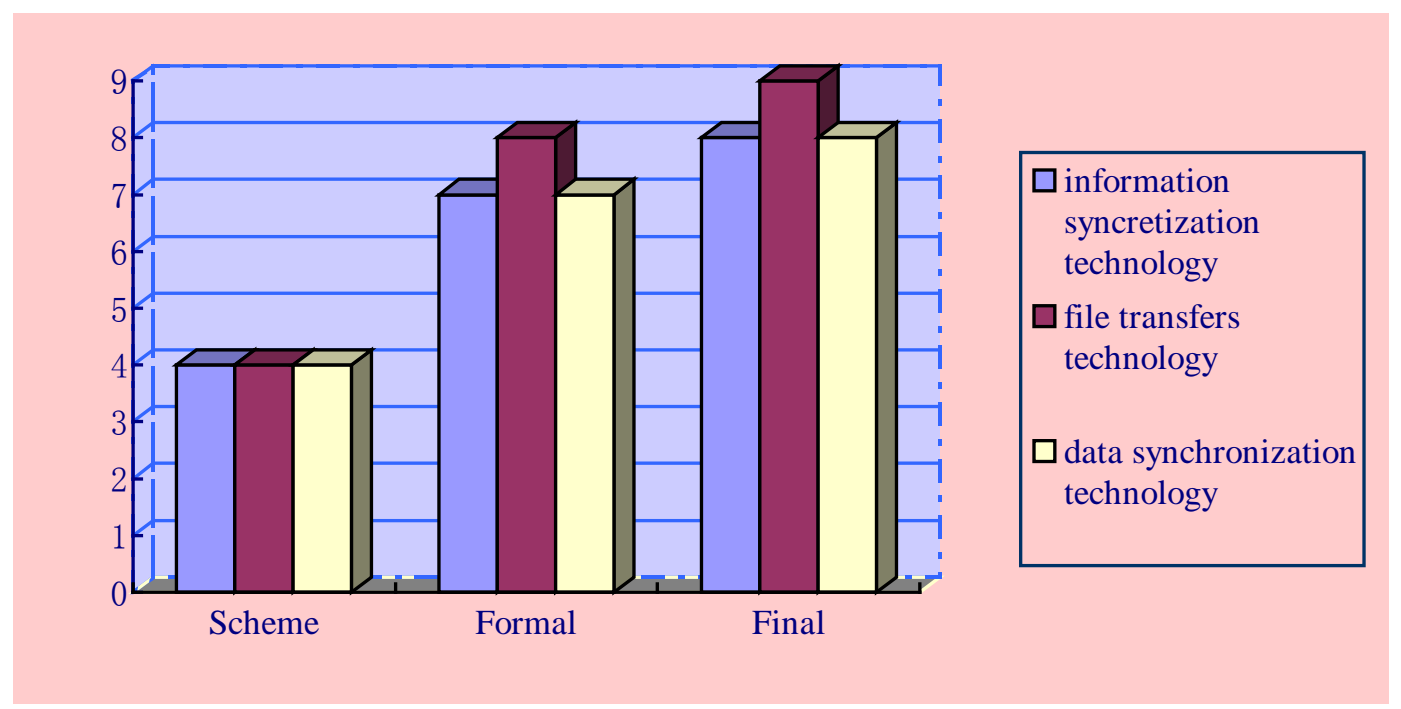

Fig.2. The TRA results of the information processing system

\section{Conclusions}

In the light of engineering process approach and technology readiness theory of electronic information system, we should fully promote the application of the technology readiness model and methods to the system development. Moreover, we need strengthen overall scheme, reinforce assessment basis, and consolidate process management. We should constantly strive for the combination of technology evolution rules with concurrent engineering thinking, so that electronic information system could be fully ensured to have more satisfying technology capabilities. 


\section{Acknowledgement}

We are grateful to the experts and secretaries for their guidance, insight and patience; they are a constant source of support and encouragement.

\section{References}

[1] Hengzhi Chu, Xiangge Zeng. Application Research of Technology Readiness Assessment in Aviation Equipment Development [C]. The fifthly youth technology forum of China aeronautics association, 2012 (10) 211-216.

[2] Wenyuan Cheng. Research on Technology Readiness Assessment Model for Larger System [J]. Aeronautical Science \& Technology, 2013 (6) 55-59.

[3] Maochun An. Technology Maturity Assessment and Application [J]. Computer Measurement \& Control, 2012 (12) 3277-3279.

[4] Xinguo Zhang. The application of Technology Readiness Theory in equipment system engineering[M]. Beijing: Defense Industry Press, 2013.

[5] Yuesheng Li, Guoning Liu, Yun Hu, Yanhui Ma. Technology Readiness Assessment and its Application in Rendezvous and Docking Mission [J]. Manned Spaceflight, 2013 (6) 51-57.

[6] Yilin Zhu. A study of influence of technology readiness level on spacecraft development schedule[J]. Spacecraft Engineering, 2009 (2) 13-17. 